\title{
SUBTITUSI TEPUNG TERIGU DENGAN TEPUNG UBI BANGGAI (Dioscorea spp) TERHADAP MUTU ORGANOLEPTIK BISKUIT
}

\section{SUBTITUTION OF WHEAT FLOUR WITH BANGGAI YAM FLOUR (Dioscorea spp) ON ORGANOLEPTIC QUALITY OF BISCUIT}

\author{
Fitriani Basrin $^{1 *}$, Tomotius Babe ${ }^{1}$ \\ ${ }^{1}$ Program Studi Program Studi Teknologi Pengolahan Hasil Laut, Politeknik Palu \\ Jln. Sinarkemuning 1 No. 1A Palu 94118 Sulawesi Tengah, Indonesia
}

\begin{abstract}
ABSTRAK
Penelitian ini bertujuan, untuk mengetahui pengaruh subtitusi tepung terigu dengan tepung ubi banggai (dioscorea spp) terhadap mutu organoleptik biskuit. Rancangan perlakuan pada penelitian subtitusi tepung terigu dengan tepung ubi banggai (dioscorea spp) terhadap mutu organoleptik biskuit yaitu: P0 (400 gram tepung terigu), P1 (100 gram tepung ubi banggai +300 gram tepung terigu), P2 (200 gram tepung ubi banggai +200 gram tepung terigu), P3 (300 gram tepung ubi banggai +100 gram tepung terigu), dan P4 (400 gram tepung ubi banggai). Rancangan percobaan yang digunakan adalah Rancangan Acak Legkap (RAL) dengan 5 perlakuan dan 4 ulangan. Hasil uji organoleptik yang meliputi rasa, warna, tektur, dan aroma yang paling disukai yaitu biskuit P1 (100 gram tepung ubi banggai +300 gram tepung terigu) dengan nilai rata-rata rasa 5.02 (agak suka), warna 4.56 (biasa/netral), tekstur 4.86 (biasa/netral), dan aroma 4.57 (biasa/netral).
\end{abstract}

Katakunci : biskuit, organoleptik, subtitusi, tepung terigu, ubi Banggai (Dioscorea spp)

\section{ABSTRACT}

This study aims to determine the effect of substitution of wheat flour with proud cassava flour (dioscorea spp) on organoleptic quality of biscuits. The treatment design in the substitution study of wheat flour with proud yam flour (dioscorea spp) on the quality of organoleptic biscuits is: PO (400 grams wheat of flour), P1 (100 grams of Banggai yam flour +300 grams of wheat flour), P2 (200 grams of Banggai yam flour +200 grams of wheat flour), P3 (300 grams of Banggai yam flour +100 grams of wheat flour), and P4 (400 grams of Banggai yam flour). The experimental design used was Randomized Block Design (CRD) with 5 treatments and 4 replications. The organoleptic test results that included the most preferred taste, color, texture, and aroma were P1 biscuits (100 grams of Banggai yam flour +300 grams of wheat flour) with an average value of 5.02 (rather like), color 4.56 (normal / neutral), texture 4.86 (normal / neutral), and aroma 4.57 (normal / neutral).

Keywords: biscuit, organoleptic, subititution, wheat flour, Banggai yam (Dioscorea spp)

\section{Pendahuluan}

Biskuit adalah produk makanan kering yang dibuat dengan caramemanggang adonan yang mengandung bahan dasar tepung terigu, lemak danbahan pengembang dengan atau tanpa penambahan bahan lain yang diizinkan.Biskuit seringkali dikonsumsi sebagai makanan selingan disampingmakanan pokok.

Sebagai makanan selingan, diharapkan dapat menyumbangkanenergi, sebagai pengganti

\footnotetext{
*) Penulis Korespondensi.

E-mail: fitrianibasrin014@gmail.com.

HP : 085256652955
}

energi yang telah dikeluarkan setelah melakukanaktivitas. Dalam hal ini, tentunya jumlah yang dikonsumsi tidak dalam porsi yangbesar, karena sifatnya hanya sebagai penyumbang energi dan zat gizi, bukansebagai pengganti menu utama. Biskuit juga memiliki kandungan protein, lemakdan beberapa mineral yang dibutu hkan oleh tubuh, sehingga sangat baik untuk dikonsumsi bagi manusia (Nugroho 2006).

Selama ini, kebanyakan biskuit dibuat dari bahan dasar tepung terigu yangberasal dari gandum yang kebutuhannya mayoritas masih diimpor. Padahalbanyak sumber karbohidrat 
lokal yang belum dimanfaatkan secara baik, yang dapat menganti tepung terigu. Salah satusumber karbohidrat lokal yang kurang dimanfaatkan secara baik adalah ubi Banggai. Selama ini, ubi Banggai hanya dikenal sebagai bahan pangan utama yang dikonsumsi oleh masyarakat Banggai, oleh karena itu perlu adanya diversifikasi produk dengan cara pembuatan tepung ubi Banggai.

Tepung ubi Banggai merupakan butiranbutiran halus yang berasal dari ubi banggai yang melalui beberapa tahapan penting, yaitu: pengupasan, pengeringan, penggilingan, dan pengayakan. Pengolahan ubi banggai menjadi bentuk tepung lebih baik dibandingkan dijadikan ubi rebus, karena tepung lebih tahan disimpan, mudah dicampur, dapat diperkaya dengan zat gizi, dan lebih praktis serta mudah digunakan untuk proses pengolahan lanjutan yaitu biskuit.

Adanya kebutuhan akan alternatif pangan bergizi dengan harga terjangkau membuka peluang untuk memproduksi biskuit dari tepung ubi Banggai. Pasar produk biskuit ubi Banggai masih terbuka lebar dan persaingan belum ketat. Selain itu, teknologi pembuatan biskuit ubi Banggai tidak terlalu rumit dan dapat menggunakan peralatan yang sederhana, serta ketersediaan bahan baku untuk pembuatan biskuit ini cukup melimpah.

\section{Tujuan}

Tujuan dalam penelitian ini adalah, mengetahui pengaruh subtitusi tepung terigu dengan tepung ubi banggai (Dioscorea spp) terhadap mutu organoleptik biskuit.

\section{Metode Penelitian}

\section{Alat dan Bahan}

Peralatan yang digunakan dalam penelitian ini adalah: pisau, plastik, rolling pin, mixser, baskom sedang, timbangan analitik, kompor, oven, cetakan dan talang, oven, timbangan analitik, cawan, desikator dan penjepit.

Sedangkan bahan-bahan yang digunakan pada penelitian ini adalah tepung terigu, tepung ubi banggai jenis pusus, tepung gula, margarin, kuning telur, susu full cream baking powder, garam dan vanili.

\section{Metode}

Penelitian ini menggunakan Rancangan Acak Lengkap (RAL) dengan perlakuan subtitusi tepung terigu dengan tepung ubi banggai. Adapun formulasitepung terigu dan tepung ubi banggai yaitu:
$\mathrm{P}_{0}: 400$ gram TT

$\mathrm{P}_{1}: 100$ gram TUB +300 gram TT

$\mathrm{P}_{2}: 200$ gram TUB +200 gram TT

$\mathrm{P}_{3}: 300$ gram TUB +100 gram TT

$\mathrm{P}_{4}: 400$ gram TUB

Perlakuan diulang sebanyak 4 kali, sehingga terdapat 20 unit percobaan. Pengacakan perlakuan dilakukan langsung terhadap 20 unit percobaan,

\section{Pelaksanaan Penelitian}

Dalam pelaksanaan penelitian ini dilakukan dua tahapan, yaitu pembuatan tepung ubi banggai dan pembuatan biskuit dengan subtitusi tepung terigu dengan tepung ubi banggai.

Pembuatan Tepung Ubi Banggai (Dioscorea spp)

Sebelum pembuatan biskuit, terlebih dahulu dilakukan pembuatan tepung ubi banggai. Cara pembuatan tepung ubi banggai ini adalah dilakukan pengupasan kulit, kemudian dicuci bersih, kemudian pengecilan ukuran.Setelah itu dilakukan pengeringan dengan menggunakan sinar matahari sampai benar-benar kering, kemudian digiling menggunakan blender, terakhir adalah penepungan, dilakukan dengan menggunakan ayakan sehingga diperoleh tepung ubi banggai yang butirannya halus.

Pembuatan Biskuit dengan Subtitusi Tepung Terigu dan Tepung Ubi Banggai (Dioscorea spp)

Setelah tahap pertama selesai dilakukan,dilanjutkan dengan tahap kedua. Pada pembuatan biskuit ubi banggai ini, diberikan perlakuan subtitusi tepung terigu dengan tepung ubi banggai. Pembuatan biskuit dengan subtitusi tepung terigu dengan tepung ubi banggai adalah: margarin, kuning telur dan gula halus dimixer dalam satu wadah selama 5 menit dengan kecepatan sedang sampai mengembang. Setelah mengembang, tambahkan susu bubuk, garam, baking powder, vanili, tepung terigu dan tepung ubi banggai, lalu mixer kembali hingga homogen. Setelah menjadi adonan, kemudian diletakkan didalam plastik dan digiling menggunakan rolling pin. Setelah itu dicetak menggunakan cetakan, biskuit yang telah dicetak diletakkan kedalam talenan oven yang sudah diolesi margarin pada permukaannya. Kemudian dipanggang selama 15 menit dengan suhu $150{ }^{\circ} \mathrm{C}$. Biskuit yang sudah matang di dinginkan, kemudian siap diuji organoleptik (warna, aroma, rasa dan tekstur). 
Tabel 1. Komposisi Biskuit

\begin{tabular}{ccccccccccc}
\hline $\mathrm{N}$ & Perlakuan & $\begin{array}{c}\text { TUB } \\
\text { (gr) }\end{array}$ & $\begin{array}{c}\text { TT } \\
\text { (gr) }\end{array}$ & $\begin{array}{c}\text { Kuning } \\
\text { Telur } \\
\text { (gr) }\end{array}$ & $\begin{array}{c}\text { Margarin } \\
\text { (gr) }\end{array}$ & $\begin{array}{c}\text { Gula } \\
\text { (gr) }\end{array}$ & $\begin{array}{c}\text { Garam } \\
\text { (gr) }\end{array}$ & $\begin{array}{c}\text { Susu } \\
\text { full } \\
\text { cream } \\
\text { (gr) }\end{array}$ & $\begin{array}{c}\text { Vanili } \\
\text { (gr) }\end{array}$ & $\begin{array}{c}\text { Baking } \\
\text { powder } \\
\text { (gr) }\end{array}$ \\
\hline 1 & P0 & - & 400 & 50 & 200 & 120 & 1 & 50 & 2 & 1 \\
2 & P1 & 100 & 300 & 50 & 200 & 120 & 1 & 50 & 2 & 1 \\
3 & P2 & 200 & 200 & 50 & 200 & 120 & 1 & 50 & 2 & 1 \\
4 & P3 & 300 & 100 & 50 & 200 & 120 & 1 & 50 & 2 & 1 \\
5 & P4 & 400 & - & 50 & 200 & 120 & 1 & 50 & 2 & 1 \\
\hline
\end{tabular}

(Hasil modifikasi)

\section{Pengamatan}

Parameter pengamatan pada penelitian ini yaitu rasa, warna, tekstur, aroma. Pada pengamatan rasa, warna, tekstur, dan aroma di uji menggunakan uji hedonik (kesukaan) dengan 25 orang panelis tidak terlatih dengan skala penilaian dapat dilihat pada tabel dibawah. Tabel 2. Kriteria Skala Hedonik (Uji Kesukaan)

\begin{tabular}{cc}
\hline Skala Hedonik & Skala Numerik \\
\hline Sangat suka & 7 \\
Suka & 6 \\
Agak Suka & 5 \\
Biasa/Netral & 4 \\
Agak Tidak Suka & 3 \\
Tidak Suka & 2 \\
Sangat Tidak suka & 1 \\
\hline
\end{tabular}

Sumber: Apriyantono $d k k$, (2010).

\section{Hasil dan Pembahasan}

\section{Rasa}

Rasa merupakan tanggapan atas adanya rangsangan kimiawi yang sampai di indera pengecap lidah, khususnya jenis rasa dasar yaitu manis, asin, asam, dan pahit. Rasa suatu produk mempengaruhi tingkat penerimaan konsumen. Walaupun parameter yang lainnya baik, jika rasanya tidak disukai maka produk tersbut akan ditolak (Rochima, $d k k$. 2015).

Hasil survei organoleptik rasa pada 25 panelis terhadap penambahan tepung ubi banggai diperoleh data nilai kesukaan panelis pada uji organoleptik rasa berkisar antara 3.96 (agak tidak suka) sampai dengan 5.02 (agak suka) dari 7 skala. skala penerimaan panelis tertinggi untuk parameter rasa pada biskuit subtitusi tepung ubi banggaiterdapat pada P1 (100 gram tepung ubi banggai +300 gram tepung terigu) dan penerimaan terendah terdapat pada P2 (200 tepung ubi banggai +200 gram tepung terigu).
Hasil rata-rata rasa biskuit disajikan pada gambar histogram dibawah ini.

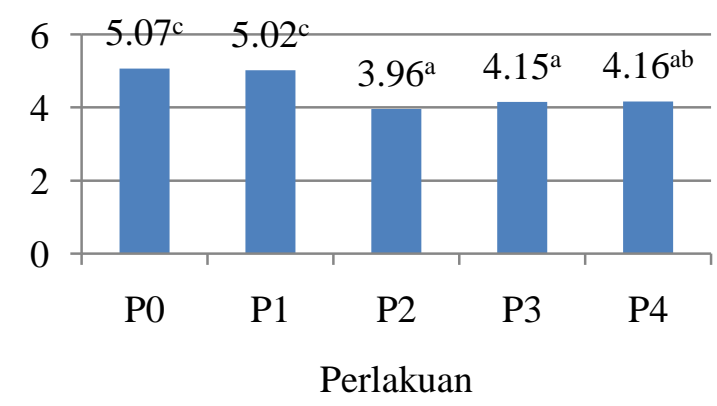

Gambar 1. Histogram rata-rata rasa biskuit

Berdasarkan gambar 1 diketahui bahwa skala penerimaan panelis tertinggi untuk parameter rasa pada biskuit subtitusi tepung ubi banggaiterdapat pada P1 (100 gram tepung ubi banggai +300 gram tepung terigu) dan penerimaan terendah terdapat pada P2 (200 tepung ubi banggai +200 gram tepung terigu). Hal ini disebabkan karena panelis belum terbiasa dengan biskuit yang mempunyai rasa tepung ubi banggai yang terlalu dominan, karena produk biskuit dari tepung ubi banggai belum beredar luas di kalangan masyarakat, padahal tepung ubi banggai mempunyai kabohidrat yang tinggi. Selain itu terdapat rasa pahit pada biskuit seiring meningkatanya presentase tepung ubi banggai. Pratama (2015), mengemukakan bahwa rasa pahit biskuit dapat disebabkan oleh hidrolisis asam-asam amino yang terjadi pada reaksi maillard, misalnya saat pemanggangan biskuit. Terdapat asam-asam amino yang menimbulkan rasa pahit seperti lisin, valin, arginin, prolin, dan fenilalanin. Asam amino lisin merupakan asam amino yang memiliki rasa paling pahit dibandingkan asam amino lainnya

Pada gambar 1 menunjukkan bahwa P0 (400 gram tepung terigu) tidak berbeda nyata terhadap P1 (100 gram tepung ubi banggai +300 
gram tepung terigu) tetapi berbeda nyata terhadapap P2, P3, dan P4. Sedangkan P2 (200 gram tepung ubi banggai +200 gram tepung terigu) tidak berbeda nyata terhadap P3 (300 gram tepung ubi banggai +100 gram tepung terigu) dan P4 (400 gram tepung ubi banggai).

\section{Warna}

Warna merupakan faktor dominan dalam parameter kenampakan yang mempengaruhi skala penerimaan biskuit karena warnadapat memberikan tanda terjadinya perubahan kimia pada suatu produk pangan dan secara visual faktor warna akan tampil terlebih dahulu dibandingkan dengan bentuk dan ukuran (Butar, 2017).

Hasil survei organoleptik warna pada 25 panelis terhadap penambahan tepung ubi banggai diperoleh data nilai kesukaan panelis pada uji organoleptik warna berkisar antara 4.37 (biasa/netral) sampai dengan 4.56 (biasa/netral) dari 7 skala. skala penerimaan panelis tertinggi untuk parameter warna pada biskuit subtitusi tepung ubi banggai terdapat pada P1 (100 tepung ubi banggai +300 gram tepung terigu), hal ini disebkan karena warna yang ditimbulkan masih utuh dan cerah sama seperti pada perlakuan kontrol (P0).

Hasil rata-rata warna biskuit disajikan pada gambar histogram dibawah ini.

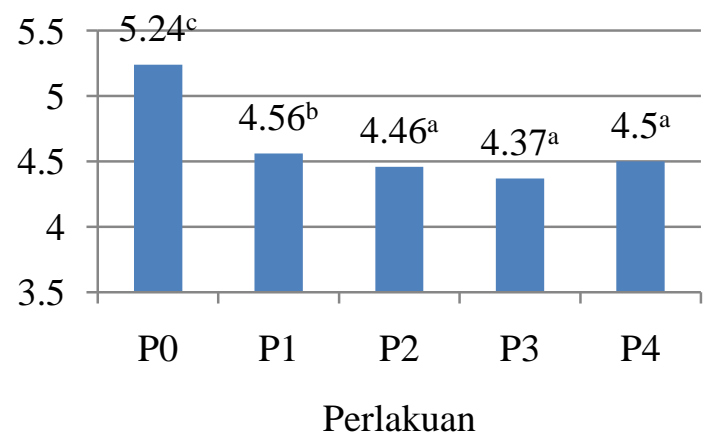

Gambar 2 . Histogram rata-rata warna biskuit

Berdasarkan gambar 2 diketahui bahwa skala penerimaan panelis tertinggi untuk parameter warna pada biskuit subtitusi tepung ubi banggaiterdapat pada P1 (100 tepung ubi banggai + 300 gram tepung terigu), hal ini disebkan karena warna yang ditimbulkan masih utuh dan cerah sama seperti pada perlakuan kontrol (P0). Warna yang ditimbulkan pada P0 dan P1 adalah warna kuning. Sedangkan penerimaan terendah terdapat pada P3 (300 tepung ubi banggai +100 gram tepung terigu), hal ini disebkan karena warna yang ditimbulakan adalah warna yang tidak konsisten yaitu warna coklat kekuningan sehingga para panelis tidak menyukaiya. Namun pada P4 mengalami kenaikan tingkat kesukaan dibandingkan dengan $\mathrm{P} 2$ dan $\mathrm{P} 3$, hal ini disebkan karena warna yang ditimbulkan konsisten yaitu warna coklat, sehingga para panelis menyukainya. Menurut Pratama (2015), warna coklat diakibatkan oleh beberapa faktor yaitu, reaksi maillard; kadar gula, serat, dan senyawa fenol yang tinggi; serta suhu pengovenan yang lama.

Pada gambar 2 menunjukkan bahwa P0 (400 gram tepung terigu) berbeda nyata terhadap P1, P2, P3, dan P4. P3 (300 gram tepung ubi banggai +100 gram tepung terigu) tidak berbeda nyata terhadap P2 (200 gram tepung ubi banggai + 200 gram tepung terigu) dan P4 (400 gram tepung ubi banggai), tetapi berbeda nyata terhadap P1 (100 gram tepung ubi banggai +300 gram tepung terigu).

\section{Tekstur}

Tekstur merupakan sensasi tekanan yang dapat diamati dengan mulut (pada waktu digigit, dikunyah dan ditelan) ataupun perabaan dengan jari. Pada biskuit, tekstur merupakan atribut produk yang cukup penting karena biskuit biasanya dinilai dari teksturnya. Setiap bentuk makanan mempunyai sifat tekstur tersendiri tergantung pada keadaan fisik, ukuran dan bentuk sel yang dikandungnya. Penilaian tekstur dapat berupa kekerasan, elastisitas atau kerenyahan (Lopulalan, 2008).

Tekstur memiliki pengaruh yang teramat penting terhadap produk, yang menjadikan produk tersebut layak untuk disukai, namun tingkat kesukaan terhadap tekstur merupakan hal yang sulit dimengerti, hal ini karena selera setiap orang yang berbeda. Proses substitusi tepung ubi banggai dalam formula biskuit yang lebih disukai adalah pada P1 (100 gram tepung ubi banggai + 300 gram tepung terigu). Perbedaan penilaian panelisterhadap tekstur biskuit dapat dilihat pada gambar 3.

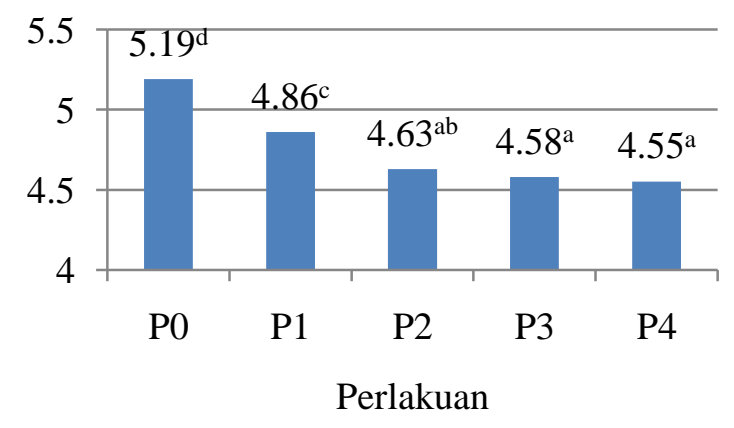

Gambar 3. Histogram rata-rata tekstur biskuit 
Berdasarkan gambar 3 menunjukan bahwa semakin banyak penambahan tepung ubi banggai maka semakin rendah daya terima oleh panelis atau semakin menurun nilai rata-ratanya, hal ini disebabkan oleh adanya kandungan kimia tepung ubi banggai yang berbeda dengan tepung terigu sehinggga pembentukan adonan tidak kompak, namun pada gambar 8 menunjukkan bahwa P0 (400 gram tepung terigu) berbeda nyata terhadap P1, P2, P3, dan P4. P2 (200 gram tepung ubi banggai +200 gram tepung terigu) tidak berbeda nyata terhadap P3 (300 gram tepung ubi banggai + 100 gram tepung terigu), dan P4 (400 gram tepung ubi banggai), tetapi berbeda nyata terhadap P1 (100 gram tepung ubi banggai +300 gram tepung terigu).

Tekstur biskuit pada umunya dipengaruhi oleh bahan pembentuk adonan biskuitdan proses pemanggangan. Tekstur biskuit diduga dipengaruhi oleh penggunaantepung terigu. Penggunaan tepung terigu pada adonan biskuit dapat mempengaruhikepadatan adonan yang mana pada akhirnya mempengaruhi tekstur pada biskuittersebut, hal ini sesuai menurut (Butar, 2017) bahwa adanya tepung terigu dalam pembuatan biskuit akan menyebabkan glatinisasi pada saat proses pemanggangan yang menyebabkan biskuit memiliki tekstur yang sangat lembut.

Panelis berpendapat bahwa biskuit yang dihasilkan memiliki tekstur yang kurang konsisten, sebagian teksturnya keras dan yang lainnya agak lembek sehingga mudah pecah. Hal ini disebabkan berkurangnya penggunaan terigu sehingga pembentukam adonan biskuit menjadi lebih mudah pecah, dimana hal ini terkait dengan berkurangnya jumlah protein gluten yang terkandung dalam adonan.

\section{Aroma}

Aroma merupakan salah satu variabel kunci, karenapada umumnya cita rasa konsumen terhadap produk makanan sangat ditentukan oleh aroma.Aroma lebih banyak dipengaruhi oleh pancaindera penciuman. Proses substitusi tepung ubi banggai dalam formula biskuit yang lebih disukai adalah pada P1 (100 gram tepung ubi banggai +300 gram tepung terigu). Perbedaan penilaian panelis terhadap aroma biskuit dapat dilihat pada gambar 4.

Berdasarkan gambar 4 menunjukan bahwa formula biskuit pada P4 (400 gram tepung ubi banggai) merupakan penerimaan panelis terendah jika dibandingkan dengan $\mathrm{P} 1, \mathrm{P} 2$, dan $\mathrm{P} 3$, hal disebkan oleh penambahan tepung ubi banggai
$100 \%$ dan aroma langu khas tepung ubi banggai yang dominan. Pada gambar 4 menunjukkan bahwa P2 (200 gram tepung ubi banggai +200 gram tepung terigu) tidak berbeda nyata terhadap P3 (300 gram tepung ubi banggai +100 gram tepung terigu), tetapi berbeda nyata terhadap P4 (400 gram tepung ubi banggai), dan P1 (100 gram tepung ubi banggai +300 gram tepung terigu), sedangkan P1 berbeda nyata terhadap P4.

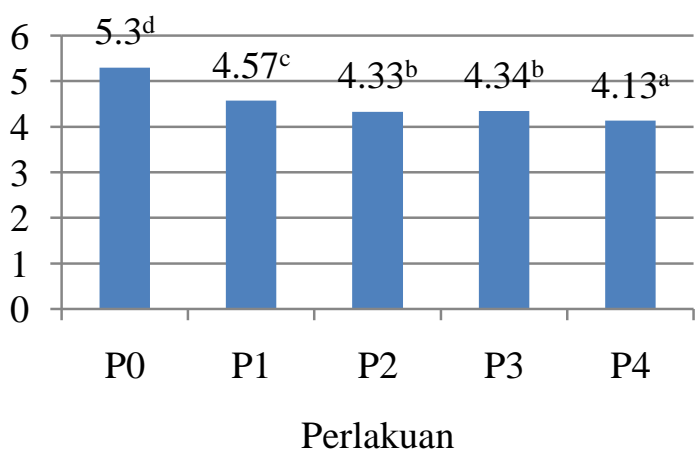

Gambar 4. Histogram rata-rata aroma biskuit

Kelezatan suatu produk ditentukan pula oleh faktor aroma. Panca indera yang paling berperan dalam penentuan kesukaan terhadap aroma adalah indera penciuman. Aroma sendiri merupakan rasa dan bau yang sangat subyektif serta sulit diukur karena setiap orang memiliki sensifitas maupun kesukaan yang berbeda-beda. Namun menurut Azizah (2015), pada umumnya aroma yang diterima oleh hidung dan otak lebih banyak merupakan campuran 4 aroma utama yaitu harum, asam, tengik dan hangus. Dalam industri makanan, pengujian terhadap aroma dianggap penting karena dapat memberikan hasil pengamatan dengan cepat. Selain aroma dapat dijadikan indikasi kelayakan pangan, juga dapat menjadi deteksi makanan memiliki rasa enak atau sebaliknya. Aroma yang sedap akan menggugah selera makan, sedangkan aroma yang tidak sedap akan menurunkan selera makan.

Daya terima terhadap aroma biskuitsubtitusi tepung ubi banggai yang paling disukai adalah biskuit substitusi 100 gram (P1),dilanjutkan biskuit substitusi 300 gram (P3), 200 gram (P2) dan 400 gram (P4).

\section{Kesimpulan dan Saran}

\section{Kesimpulan}

Berdasarkan hasil penelitian yang telah dilaksanakan disimpulkan bahwa, tingkat penerimaan rasa, warna, tekstur dan aroma pada biskuit subtitusi tepung terigu dengan tepung ubi banggai terdapat pada P1 (100 gram tepung ubi 
banggai +300 gram tepung terigu) dengan nilai rata-rata rasa 5.02 (agak suka), warna 4.56 (biasa/netral), tekstur 4.86 (biasa/netral), dan aroma 4.57 (biasa/netral).

\section{Saran}

Perlunya pengembangan penelitian lebih lanjut untuk memodifikasi teknologi pengolahan pangan baru yang berasal dari tepung ubi banggai (Dioscorea spp).

\section{Daftar Pustaka}

Apriyantono, A., Setyaningsi, D., dan Puspita, M. 2010. Analisis Sensori Untuk Industri Pangan dan Agro. Bogor: IPB Press

Azizah, A, A. 2015. Tingkat Kerapuhan Dan Daya Terima Biskuit Yang Disubstitusi Tepung Daun Kelor (Moringa Oleifera) [Naskah Publikasi]. Program Studi Ilmu Gizi Jenjang DIII, Fakultas Ilmu Kesehatan, Universitas Muhammadiyah Surakarta. Hal. 1-7

Butar, S, D. 2017. Pemanfaatan Spirulina Platensis Sebagai Biskuit Yang Tinggi Protein [Skripsi]. Jurusanan Teknologi Hasil Perikanan, Fakultas Ilmu Kelautan Dan Perikanan, Universitas Maritim Raja Ali Haji
p-ISSN : 2527-5631

Lopulalan, C, G, C. 2008. Kajian Formulasi Dan Isothermis Sorpsi Air Biskuit Jagung [Tesis]. Sekolah Pascasarjana, Institut Pertanian Bogor

Nugroho, J, S. 2006. Optimalisasi Pemanfaatan Ikan Pepetek (LeiognathusSp.) Dan Ubi Jalar Putih (Ipomoea BatatasL.) Untuk Substitusi Parsial Tepung Terigu Dalam Pembuatan Biskuit [Skripsi]. Program Studi Teknologi Hasil Perikanan Fakultas Perikanan Dan Ilmu Kelautan Institut Pertanian Bogor

Pratama, H, S. 2015. Kandungan Gizi, Kesukaan, Dan Warna Biskuit Substitusi Tepung Pisang Dan Kecambah Kedelai [Artikel Penelitian].Program Studi Ilmu Gizi, Fakultas Kedokteran, Universitas Diponegoro Semarang

Rochima, E., Pratama, I, R., dan Suhara, O. 2015. Karakterisasi Kimiawi Dan Organoleptik Pempek Dengan Penambahan Tepung Tulang Ikan Mas Asal Waduk Cirata. Jurnal Akuatika Vol. 6, No. 1, Hal. 79-86. ISSN: 0853-2532 